\title{
Produk Domestik Regional Bruto Provinsi Sumatra Barat Menurut Lapangan Usaha
}

\author{
Erlin $^{* 1}$, Erni $^{2}$, Maggie $^{3}$, Vincent $^{4}$, Zidane $^{5}$ \\ 1,2,3,4,5 Manajemen, Fakultas Ekonomi, Universitas Internasional Batam, Indonesia \\ Email: erlinntann30@gmail.com¹, erni.kwok119@gmail.com², maggiegohh@gmail.com ${ }^{3}$, \\ vincentzhen10@gmail.com ${ }^{4}$, zidanehuang9@gmail.com ${ }^{5}$
}

\begin{abstract}
Abstrak
Pertumbuhan ekonomi merupakan salah satu hal yang terpenting dalam mengukur perekonomian di Indonesia. Selain itu, pertumbuhan ekonomi juga salah satu indikator makro dalam mengukur kinerja ekonomi suatu Negara. Indikator yang dapat digunakan untuk menunjukkan kinerja ekonomi suatu daerah adalah data mengenai Produk Domestik Regional Bruto (PDRB) melalui harga yang berlaku ataupun atas dasar harga konstan. Tujuan dari proyek ini adalah untuk mengetahui perkembangan ekonomi di Sumatera Barat dan dampaknya terhadap pandemi COVID-19, metode yang kami gunakan disini yaitu teknik pengumpulan data dan analisis data, Suatu masyarakat dapat mengalami suatu pertumbuhan apabila pendapatan perkapita menurut harga atau pendapatan terus menerus bertambah. Dengan Produk Domestik Regional Bruto (PDRB) kita dapat mengevaluasi kinerja perkembangan ekonomi suatu wilayah dari tahun ke tahun yang disajikan dalam bentuk data.
\end{abstract}

Kata kunci: Data, Ekonomi, PDRB, Pertumbuhan Ekonomi

\begin{abstract}
Economic growth is one of the most important things in measuring the economy in Indonesia. In addition, economic growth is also one of the macro indicators in measuring the economic performance of a country. Indicators that can be used to show the economic performance of a region are data on Gross Regional Domestic Product (GDP) at current prices or at constant prices. The purpose of this project is to determine the economic development in West Sumatra and its impact on the COVID-19 pandemic, the method we use here is data collection and data analysis techniques. A community can experience a growth if per capita income by price or income continues to increase. With the Gross Regional Domestic Product (GDP) we can evaluate the performance of the economic development of a region from year to year which is presented in the form of data.
\end{abstract}

Keywords: Economy, Economic growth, Data, GRDP

\section{PENDAHULUAN}

Sebuah tahap peningkatan kinerja pemerintah dalam peningkatan ekonomi di setiap negara serta salah satu jenis makro dalam memantau ekonomi di suatu wilayah disebut sebagai pertumbuhan/ perkembangan ekonomi. PDRB adalah suatu kumpulan data yang digunakan untuk menilai kinerja perkembangan ekonomi wilayah (Badan Pusat Statistik, 2021). PDRB Provinsi Sumatra Barat menurut lapangan usaha merupakan suatu data yang menjelaskan PDRB menurut pendekatan lapangan usaha. Pendekatan ini terdapat beberapa kategori seperti pertanian, pertambangan dan penggalian, jasa keuangan dan asuransi dll. Gambar 1 merupakan nilai PDRB Per Kapita (Persen) Provinsi Sumatra Barat 2018-2020 (Statistik \& Barat, n.d.).

Dari data pada Gambar 1, dapat kita lihat bahwa Nilai PDRB Provinsi Sumatera Barat pada tahun 2019 sebesar 245,9 triliun rupiah, jika di banding dengan periode 2020 sebesar 242,1 triliun rupiah. Hal ini dapat kita liat bahwa nilai PDRB mengalami penurunan sebesar 3,8 triliun rupiah. Hal ini dikarenakan pandemi COVID-19 yang terjadi di Indonesia sejak Maret 2020. Dengan adanya pandemi COVID-19 mengakibatkan dampak yang cukup besar bagi perekonomian secara nasional maupun regional. 


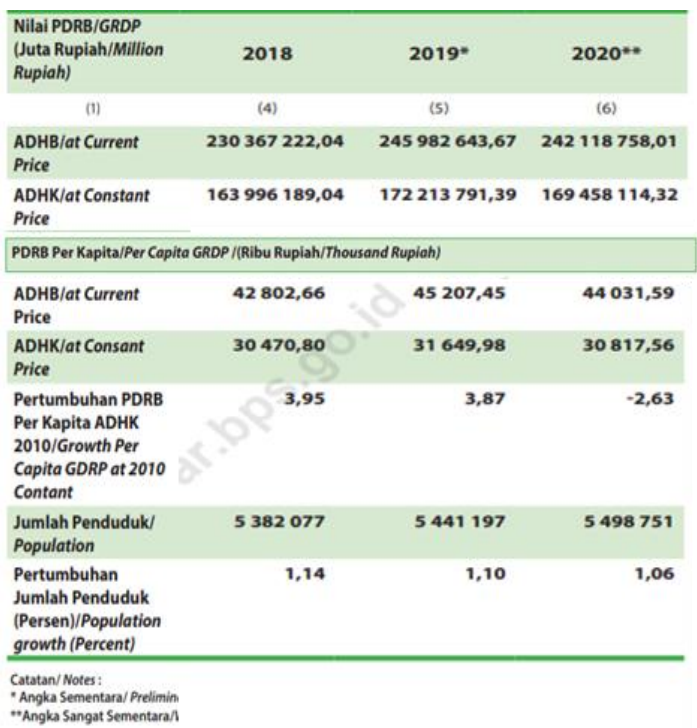

Gambar 1. Nilai PDRB Per Kapita

Dari data di atas, dapat kita lihat bahwa Nilai PDRB Provinsi Sumatera Barat pada tahun 2019 sebesar 245,9 triliun rupiah, jika di banding dengan periode 2020 sebesar 242,1 triliun rupiah. Hal ini dapat kita liat bahwa nilai PDRB mengalami penurunan sebesar 3,8 triliun rupiah. Hal ini dikarenakan pandemi COVID-19 yang terjadi di Indonesia sejak Maret 2020. Dengan adanya pandemi COVID-19 mengakibatkan dampak yang cukup besar bagi perekonomian secara nasional maupun regional.

Selanjutnya, dapat kita liat pertumbuhan ekonomi 2020 ekonomi Sumatera Barat adalah 2,23 persen bila dibandingkan dengan 2019. Pertumbuhan tertinggi adalah lapangan usaha Jasa Kesehatan sebesar 10,19\%, Informasi dan Komunikasi 8,75\% dan Jasa Pendidikan 3,35\%. Struktur perekonomian Sumatera Barat pada 2020 didominasi oleh 3 lapangan usaha yang terdiri dari: Pertanian, Kehutanan dan Perikanan (22,17\%); Perdagangan Besar-Eceran dan Reparasi Mobil-Sepeda Motor (15,51\%), Transportasi dan Pergudangan (10,31\%).

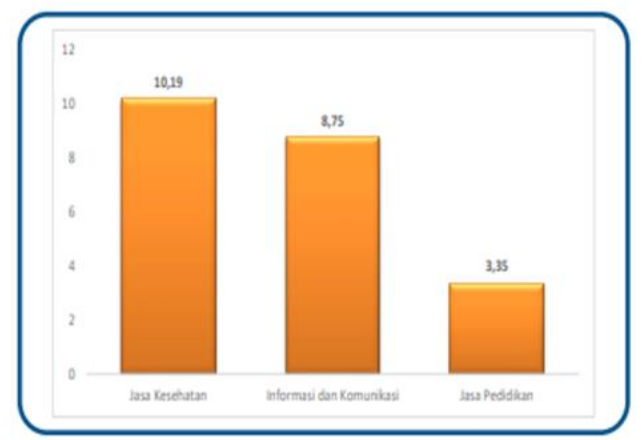

Gambar 2. Pertumbuhan PDRB Tiga Besar Lapangan Usaha Triwulan IV-2020

Adapun tujuan dari penulisan ini, diantaranya:

a. Mengetahui/mengevaluasi perkembangan perekonomian Sumatera Barat.

b. Mengetahui pertumbuhan tertinggi di Sumatera Barat.

c. Mengetahui dampak pandemi COVID-19 terhadap perkembangan/pertumbuhan ekonomi Sumatera Barat.

Dari penelitian yang telah dilaksanakan, diharapkan dapat memberikan manfaat diantaranya:

a. Diharapkan dapat membantu sumber informasi bagi pemerintah agar terciptanya peningkatan/ pengembangan pembangunan ekonomi.

b. Memberikan wawasan ilmu pengetahuan terhadap pembangunan Sumatera Barat.

c. Dapat dijadikan sebagai bahan referensi atau pengembangan untuk penelitian selanjutnya. 
Produk domestik bruto (PDB) regional adalah total nilai tambah semua barang dan jasa diciptakan atau diproduksi di dalam negeri sebuah negara dengan dibuat karena berbagai alasan suatu periode kegiatan ekonomi apakah itu baik-baik saja atau tidak faktor produksi selama periode waktu tertentu penduduk atau bukan penduduk. Penyediaan PDRB riil dapat dilakukan dengan 3 (tiga) cara yaitu metode produksi, pengeluaran, dan basis pendapatan harga saat ini dan harga konstan (BPS, 2020). PDRB pada harga saat ini atau dikenal sebagai kompilasi PDRB nominal sesuai dengan harga saat periode perhitungan dirancang untuk dilihat struktur ekonominya. Namun Kompilasi PDRB berdasarkan harga konstan tahun dasar dan dirancang ukuran pertumbuhan ekonomi. (Produk et al., 2021).

PDRB Daerah di tingkat regional (provinsi) menjelaskan kemampuan suatu area tempat output pada waktu tertentu. Menyusun PDRB, menggunakan 2 metode, yaitu produksi dan penggunaan. Keduanya melayani komposisi terperinci dari data nilai tambah sumber kegiatan ekonomi (Area bisnis) dan menurut Penggunaan komponen. PDRB dari perspektif bisnis, jumlah semua nilai komponen menambah jumlah total yang dapat dibuat melalui berbagai bidang bisnis kegiatan produksi. Meskipun dari deskripsi pengguna penggunaan dari nilai tambah tersebut (Ninla Elmawati Falabiba et al., 2014)

Penyajian PDRB di Lapangan memperkenalkan PDRB menurut bidang bisnis tersegmentasi berdasarkan bidang usaha meliputi pertanian, kehutanan dan perikanan, pertambangan dan penggalian, pengolahan, pasokan listrik dan gas alam, pasokan air, pengelolaan dan kategori lainnya. Sampah, limbah dan daur ulang, konstruksi grosir dan eceran, dan lain-lain (Badan Pusat Statistika, 2021).

Laju perkembangan PDRB daerah diperoleh dengan menghitung PDRB atas harga konstan. Tingkat pertumbuhan/peningkatan dihitung dengan mengurangkan nilai tahun $n-1$ dari nilai PDRB $n$ tahun, bagi dengan nilai pada tahun ke-n-1 dan kalikan 100\%. (BPS, 2020)

Salah satu indikator makro tampilkan status ekonomi secara nasional setiap tahun dapat membawa manfaat didapatkan dari data tersebut antara lain.

a. Harga (nominal) PDRB saat ini menunjukkan kinerja sumber daya ekonomi diproduksi oleh suatu daerah.

b. Dapat menggunakan harga konstan (aktual) PDRB tampilkan tingkat pertumbuhan ekonomi secara keseluruhan atau masing-masing klasifikasi tahunan.

c. Distribusi harga PDRB berlaku untuk area bisnis yang menunjukkan struktur ekonomi atau peran setiap orang dalam ekonomi suatu wilayah.

d. PDRB per kapita yang dihitung atas dasar harga berlaku menunjukkan nilai PDRB dan GNP per kapita.

e. PDRB per kapita dengan harga konstan membantu memahami pertumbuhan ekonomi riil per kapita bangsa.

\section{METODE PENELITIAN}

Data yang digunakan adalah data PDRB Provinsi Sumatera Barat berdasarkan harga berlaku dan dibagi berdasarkan bidang usaha dari data rangkuman 2018 - 2020. Metode ini menggunakan analisis kuantitatif, yaitu metode analisis data yang disajikan dalam bentuk data dan terkait dengan dampak perkembangan ekonomi suatu daerah dari tahun ke tahun dan dalam perhitungan angka statistik (Produk et al., 2021).

Untuk mencapai tujuan penelitian perlu dilakukan analisis faktor-faktor yang mempengaruhi PDRB Sumatera Barat berdasarkan harga berlaku di wilayah usaha. Karena penelitian ini bertujuan untuk menganalisis faktor-faktor yang mempengaruhi produk pada sektor usaha di Sumatera Barat. Maka variabel yang digunakan adalah variabel terikat yang mempengaruhi variabel bebas. Inilah sebabnya mengapa variabel dependen sering disebut sebagai variabel dependen.

Metode penelitian dilakukan agar dapat mendapatkan suatu data yang memiliki tujuan dan bermanfaat bagi kegunaannya. Agar dapat mencapai tujuannya kami membutuhkan suatu cara metode yang relevan atau cocok untuk dapat mencapai tujuan. Pada penelitian tersebut kami menggunakan metode penelitian kuantitatif. 


\subsection{Teknik Pengumpulan Data}

Data yang digunakan adalah data PDRB Provinsi Sumatera Barat berdasarkan harga berlaku dan dibagi berdasarkan bidang usaha dari data rangkuman 2018 - 2020. Metode ini menggunakan analisis kuantitatif, yaitu metode analisis data yang disajikan dalam bentuk data dan terkait dengan dampak perkembangan ekonomi suatu daerah dari tahun ke tahun dan dalam perhitungan angka statistik (Produk et al., 2021).

\subsection{Objek Penelitian}

Objek penelitian disini adalah suatu projek yang akan menjadi objek dari penelitian kami, yang nantinya akan kami analisis, dan kaji. Bisa diartikan juga sebagai sebuah sasaran untuk dapat memiliki data yang memiliki tujuan dan berguna tentang hal yang valid, objektif, dan dapat diandalkan mengenai suatu variabel tertentu. Dari objek yang akan kami teliti ini adalah mengenai daerah dari PDRB Sumatera Barat yang telah kami dapatkan data rangkuman dari tahun ke tahunnya.

\subsection{Analisis Data}

Untuk mencapai tujuan penelitian perlu dilakukan analisis faktor-faktor yang mempengaruhi PDRB Sumatera Barat berdasarkan harga berlaku di wilayah usaha. Karena penelitian ini bertujuan untuk menganalisis faktor-faktor yang mempengaruhi produk pada sektor usaha di Sumatera Barat. Maka variabel yang digunakan adalah variabel terikat yang mempengaruhi variabel bebas. Inilah sebabnya mengapa variabel dependen sering disebut sebagai variabel dependen.

\section{HASIL DAN PEMBAHASAN}

Dari tinjauan dan analisis penelitian yang telah dilakukan, bagian hasil dan pembahasan ini dapat memberikan pemahaman mengenai kondisi perkembangan Produk Domestik Regional Bruto (PDRB) pada Provinsi Sumatera Barat. PDRB pada Provinsi Sumatra Barat menurut lapangan usaha merupakan suatu data yang menjelaskan pendekatan lapangan usaha yang terbagi dalam beberapa kategori seperti pertanian, pertambangan dan penggalian, jasa keuangan dan asuransi dan lain-lain.

Yang diketahui bahwa perkembangan suatu ekonomi baik dalam jasa maupun barang sangat berpengaruh terhadap nilai suatu Negara dalam menentukan struktur ekonomi (Memengaruhi et al., 2021). Struktur ekonomi yang meningkat ataupun menurun dapat menunjukkan seberapa besar kinerja suatu daerah dalam meningkatkan produksi dari setiap lapangan usahanya. Pada tahun 2020 peranan terbesar dalam PDRB Sumatra Barat didapatkan oleh lapangan usaha seperti pertanian, perikanan serta kehutanan sebesar 22,38\% angka tersebut mengalami kenaikan sebesar 0,23\% yang jika dibandingkan dengan tahun 2019 akan berpengaruh sebesar 22,15\%. Kemudian pada lapangan usaha Industri Pengolahan mengalami kenaikan sebesar $0,26 \%$ jika di bandingkan dengan tahun 2019. Pada konstruksi memengaruhi kenaikan sekitar $0,10 \%$ informasi serta Komunikasi mengalami kenaikan 0,63\%, Jasa Keuangan dan Asuransi mengalami kenaikan 0,13\%, Real Estat kenaikan sebesar 0,5\%, Administrasi Pemerintahan, Pertahanan dan Jaminan Sosial Wajib mengalami kenaikan 0,58\%. Jasa Ilmu atau pendidikan naik $0,35 \%$, Untuk medical atau kesehatan serta aktivitas sosial lainnya mengalami kenaikan sekitar $0,20 \%$.

Data dalam penelitian ini digunakan dari data PDRB Provinsi Sumatera Barat berdasarkan harga berlaku dan bidang usaha dari data rangkuman 2018 - 2020 dengan metode analisis kuantitatif, yaitu metode analisis yang disajikan dalam bentuk data yang terkait dengan dampak perkembangan ekonomi suatu daerah dari tahun ke tahun dan dalam perhitungan angka statistik (Produk et al., 2021).

Jika dilihat dari data tersebut, hal yang menyebabkan penurunan dan peningkatan PDRB Sumatra Barat tahun 2020 dikarenakan munculnya pandemi COVID-19 yang memiliki dampak lumayan besar terhadap masing-masing lapangan usaha. Berikut data Persentase PDRB Provinsi Sumatera Barat Atas Dasar Harga Berlaku Menurut Lapangan Usaha pada tahun 2018-2020. 


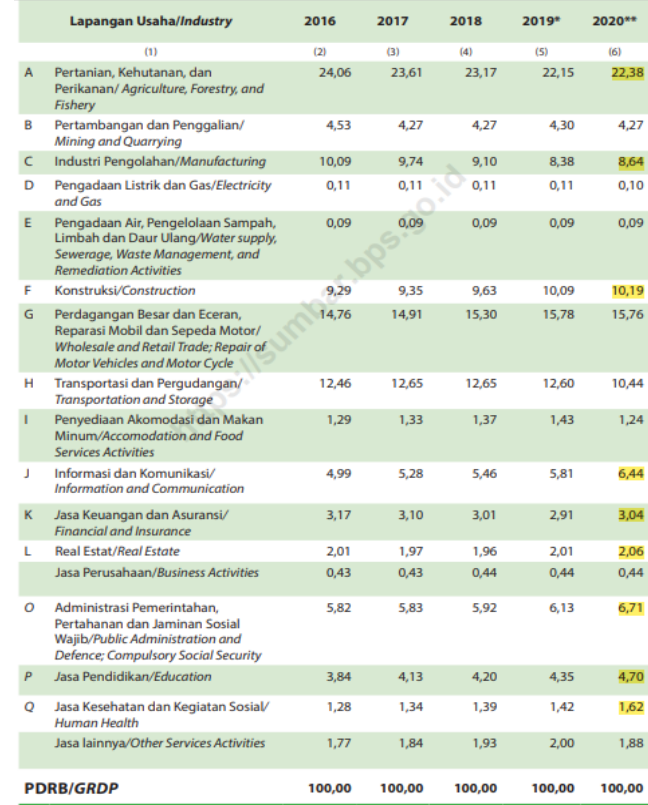

Gambar 3. data Persentase Produk Domestik Regional Bruto Provinsi Sumatera Barat 2018-2020

Dapat disimpulkan bahwa tujuan dan manfaat dilakukan tinjauan analisis pada penelitian ini digunakan untuk mengetahui dan mengevaluasi kinerja perkembangan perekonomian dan pertumbuhan tertinggi di Sumatera Barat serta dapat memberikan wawasan ilmu pengetahuan dengan menganalisis faktor-faktor yang mempengaruhi produk dan pembangunan pada sektor usaha di Sumatera Barat agar dapat menjadi sumber informasi untuk meningkatkan dan mengembangkan pembangunan ekonominya.

\section{KESIMPULAN}

Kesimpulan kami Produk Domestik Regional Bruto (PDRB) adalah suatu kumpulan data ekonomi yang dapat digunakan untuk mengevaluasi kinerja perkembangan ekonomi suatu wilayah (provinsi/kabupaten/kota). dari data persentase PDRB Provinsi Sumatera Barat dari 2018-2020 mengalami naik turun terlebih lagi pada 2020 terjadi penurunan yang cukup parah dikarenakan pandemi virus COVID-19 bisa dilihat data pada 2020 mengalami penurunan dari berbagai seKtor persentase PDRB dibandingkan tahun- tahun sebelumnya.

Kami merekomendasikan pemerintah Provinsi Sumatera Barat harus memperketat protokol kesehatan agar penyebaran virus COVID-19 tidak menyebar luas seperti penggunaan masker disaat keluar rumah, handsanitizer dibawa kemana-mana, dan bisa juga menutup ruas jalan suatu wilayah yang tingkat penyebaran COVID-19-nya berkembang pesat, menurut kami PSBB perlu dilaksanakan tetapi tidak dianjurkan terus menerus karena dapat berefek pada ekonomi daerah tersebut, selain itu mencari inovasi lebih lanjut dalam bidang tertentu agar mengalami peningkatan yang memadai supaya persentase PDRB pada tahun selanjutnya tidak semakin menurun melainkan berkembang.

\section{DAFTAR PUSTAKA}

Badan Pusat Statistik. (2021). Hasil sensus penduduk (SP2020) pada September 2020 mencatat jumlah penduduk sebesar 270,20 juta jiwa. September, 1-6. https://www.bps.go.id/publication/2021/01/21/213995c881428fef20a18226/potret-sensuspenduduk-2020-menuju-satu-data-kependudukan-indonesia.html

Badan Pusat Statistika. (2021). Berita Resmi Statistik (5 Februari 2021). Bps.Go.Id, 27, 1-16.

BPS. (2020). Pertumbuhan Ekonomi Sumatera Barat. 28, 1-12.

Memengaruhi, Y., Lim, A., Wolvinson, A., Wibowo, R., \& Chen, S. (2021). Analisis Pendapatan 
Regional Wilayah Jawa Tengah Beserta Faktor-Faktor. 1(6), 465-471.

Ninla Elmawati Falabiba, Anggaran, W., Mayssara A. Abo Hassanin Supervised, A., Wiyono, B. ., Ninla Elmawati Falabiba, Zhang, Y. J., Li, Y., \& Chen, X. (2014). 済無No Title No Title No Title. Paper Knowledge . Toward a Media History of Documents, 5(2), 40-51.

Produk, P., Regional, D., Provinsi, B., Barat, S., Pengolahan, I., Air, P., Akomodasi, P., Estat, R., Perusahaan, J., \& Pemerintahan, A. (2021). Terbuka pengisian Survei Kegiatan Usaha pada Masa Pandemi COVID-19 melalui link berik Produk Domestik Regional Bruto Provinsi Sumatera Barat Menurut Lapangan Usaha 2016-2020 Facebook Twitter Berita Resmi Statistik Publikasi pasi dalam. 2020-2021.

Statistik, B. P., \& Barat, P. S. (n.d.). Catalog : 9302001.13. 